\title{
Issues and Problems Faced by Rural Farmers in Paddy Cultivation: A Case Study of the Iban Paddy Cultivation in Kuala Tatau, Sarawak
}

\author{
Daniel Ugih Echoh ${ }^{1}$, Norizan Md Nor ${ }^{1}$, Salfarina Abdul Gapor ${ }^{2}$ \& Tarmiji Masron $^{3}$ \\ ${ }^{1}$ School of Humanities' Universiti Sains Malaysia' 11800 Penang 'Malaysia; ${ }^{2}$ School of Built Environment, \\ University College of Technology Sarawak, 96000 Sibu, Sarawak; ${ }^{3}$ Faculty of Social Sciences Universiti \\ Malaysia Sarawak 94300 Kota Samarahan, Sarawak. \\ *Corresponding author, e-mail: danielusm@ hotmail.my
}

(Received: 9 May 2017; Accepted: 19 July 2017)

\begin{abstract}
Rice is an important staple food in Asia. However, modernization and rapid development have reduced and threatened the practice, especially maintaining traditional hill rice cultivation, as in this case study by the Iban in Kuala Tatau located in the largest state in Malaysia, called Sarawak. It is important to understand the problems and challenges of this issue to ensure food security among the rural population in Sarawak, particularly the Iban. Therefore, this paper aims to discuss the issues and problems faced by rice farmers in Kuala Tatau, Sarawak. The respondents were Iban farmers in Kuala Tatau; named Sungai Semanok and Kuala Serupai, were selected as it is at a great distance from urban areas named Bintulu, and they still practices paddy cultivation. For the purpose of obtaining the data, qualitative research methods through in-depth interview techniques, group discussion and observation were utilized and the data were analyzed using content analysis. The results showed that the rice sector faced major problems such as the decrease of the number of farmers and a weak system in the distribution of subsidies. However, there were differences shown in results between the two villages as well, which were in term of inadequate agricultural land, and issues on drainage and irrigation system, depending on the distance of the village from urban area, transport facilities, and other issues as discussed in the following section.
\end{abstract}

Keywords: agriculture, paddy, rural, Sarawak, sustainability.

\section{INTRODUCTION}

The agricultural sector is an important sector for the Malaysian economic development after manufacturing and services sector. Since the 1960s, the agricultural sector plays an important role in providing food supplies to accommodate the growing population, reduces unemployment, as a source of export earnings, provides raw materials for agro-industrial growth and so on (Arshad, 2008). This sector is also a main economic activity in rural Malaysia such as in Sarawak. Sarawak was listed as one of the highest poverty rates in Malaysia since independence, especially in the rural areas, whereby most of the farmers were poor, living in rural area and commonly associated with paddy is an important agricultural activity for the agricultural sector (Madeline, 1995). Hill paddy is an important agricultural activity for the Iban. Generally, paddy cultivation activity is just for their self-sufficiency and they sell the surplus to buy basic needs for instance sugar, salt, petrol and sometimes for special case expenditure such as education, especially during the end of year before the school activity begins (Daniel Ugih, 2014). Refer to Walton (1990) and Madeline (1995), the production of hill paddy by swidden system is only approximately 750 kilograms per hectare compared with wet paddy output of 2,000 kilograms per hectare. In the interior, the 
soils have low nutrients and of low quality, low population density and low technology making the swidden system a suitable agricultural method. Swidden system refers as a technique of rotational farming which land is cleared for cultivation and left to regenerate after a few years. This system is important in Sarawak due to high acidic soil which is not suitable for agricultural activities. Therefore, the farmers need to change the cultivation site rotately. In the 1970s, 1980s and 1990s, the developing countries such as Malaysia, Indonesia, Thailand and others fell into an external debt-led financial crisis. In the first phase of these crises, the inability to service debt was contributed by many factors including depression of commodity export prices, increase in the price of oil imports, a rapid increase in foreign loans and the inability to utilize these loans productively or appropriately.

In response to this problem, Malaysia government had introduced the national economic approach from agricultural economic based to industrial economic based. The main objective of this new economic approach is to redistribute wealth, promote export, substitute imports, as well as strengthening and consolidating the sectors that would be exposed to foreign competition. This approach has created job opportunities for the local people and decrease the number of poverty rates in this country. Manufacturing industries has attracted investors to invest in Malaysia and generating more job vacancies due the multiplier economic effects from the industries.

Plus, infrastructure development has improved the linkages between urban and rural area, which recorded in higher rate of poverty. Hence, the rural area person, especially farmers, has an easy access to sell their agriculture yields to urban area. It also contributes to the rapid urbanization process such as, Georgetown, Lembah Klang, Johor Bahru, Kuala Lumpur, Kota Kinabalu in Sabah, Miri and Bintulu in Sarawak. However, the consequences of these policies on the agricultural sector have generally caused a decrease in the number and income levels of farmers and reduced the size of agricultural lands. It also promotes migration from rural to urban areas as well as perceived unattractiveness of this sector to the youths, hence resulted in a contraction of the agricultural sector's human capital. In the context of Kuala Tatau, there are numerous issues and challenges that occur in the rural paddy cultivation especially among the Iban farmers.

The main reason for this study, to date is there has been a lack of research on this issues, particularly in the sense of giving greater focus on the issues of paddy cultivation in rural area. This is in line with the rapidly urbanization and industrialization process in Sarawak. Based on the experience in developed countries, land use has changed from agricultural activities to industrial and urbanization purposes. It lead to the decreasing of agricultural land and labor migration from agricultural sector to industrial sector due, to a better wages and life quality factors.

\section{RESEARCH METHOD}

The researchers use a qualitative research method and conduct in depth interview with the farmers, focus on group discussion and also personally observed the farming activities. This study involves 17 farmers who were interviewed in both villages, where eight were from Kuala Serupai, and nine were from Sungai Semanok. The selection of these two villages is by cause of the community are still practicing paddy cultivation.

Sungai Semanok and Kuala Serupai are located 50 kilometers and 61 kilometers respectively, from Bintulu city. Sungai Semanok also connected by road to Bintulu city but the community in Kuala Serupai is still using boat to go to Bintulu city. Researcher has conducted interview with the farmers ranging from different backgrounds, age ranges, sex and also from different experiences involving in paddy farming and conducting certain ceremonial rituals associated to the paddy cultivation. In this interview, the data reached saturation. Data saturation refers to the point where the information becomes redundant as interview has received a very repetitive response from the 
interviewees; hence same patterns are seen repeatedly. The analysis of qualitative data was carried out based on the narratives obtained from in depth interviews with 17 farmers. Data was transcribed from recorded interviews of each respondent. The taped interviews were reviewed and examined at least twice before being transcribed.

This paper also obtains secondary data from previous study by government agencies, rural and agriculture development history, economic report, population census and other documents especially in the context of Sarawak. Content analysis was used as well to analyze the data. This process uses inductive reasoning, by which themes and categories emerge from the data through the researcher's careful examination and constant comparison.

\section{IBANS AND PADDY CULTIVATION IN SARAWAK}

Paddy farming is very much associated to the Iban community at the rural areas in Sarawak. In this case of study, the paddy is planted by farmers who were living at the lowlands by the coast of Sarawak such as Kuala Tatau, Kuala Balingian, Kuala Mukah, Kuala Baram and the coastal areas of Kuching. Paddy farming involves swidden system by moving from one area to another area amongst the farmers within the farmer's land. This method has been practiced by more than $76.5 \%$ of ethnic groups in the regions of Sarawak (Majid, 1982).

Typically, this swidden system involved the changing of farming lots more frequently as compared to the crop rotating method and the burning down of undergrowth and trees. These farming activities are usually done without the use of farming animals for instance when ploughing the soil and also fertilizing the soil.

However, it is completely dependent on man power to complete these farming tasks such as ploughing, transporting the harvest and so on. Some of the frequently used tools are the seedling tool and hoe. In terms of time spending, this method of farming would be done in a short period of time from one land to another while those lands are left to be "rang" lands. (Pelzer,
1945). Refer to Hoki Makoto (1977), paddy cultivation in Sarawak is greatly hampered by topographical conditions not suited for securing irrigation water in spite of its favorable climate.

For this study, two villages in Kuala Tatau (Figure 1) namely Sungai Semanok and Kuala Serupai were chosen. Both villages were chosen to enable the comparison between practices and beliefs in farming due to multiple factors, for instance the distance of both villages from Bintulu city, infrastructures and facilities availability, and the size of the population. Kuala Tatau is under the administration of Tatau District Office. Sarawak administrative system is totally different than Peninsular Malaysia whereby the state had divided into divisions headed by Resident. Tatau District is under the administration of Bintulu Resident office which is the ninth divisions in Sarawak.

Resident offices and District officers are responsible to each districts under their administrative area. District officers must be conversant with all issues, especially on socioeconomic issues. Until 2015, Sarawak has 12 divisions, 40 Districts and 26 sub-districts. Bintulu Division was a small fishing village back in 1981, then growing as a petrochemical industrial area in 1990s, up until today. In this study, both villages were chosen to enable the comparison between practices and belief in farming due to multiple factors, for instance the distant of both villages from Bintulu City, infrastructures and facilities availability, and the size of the population. 


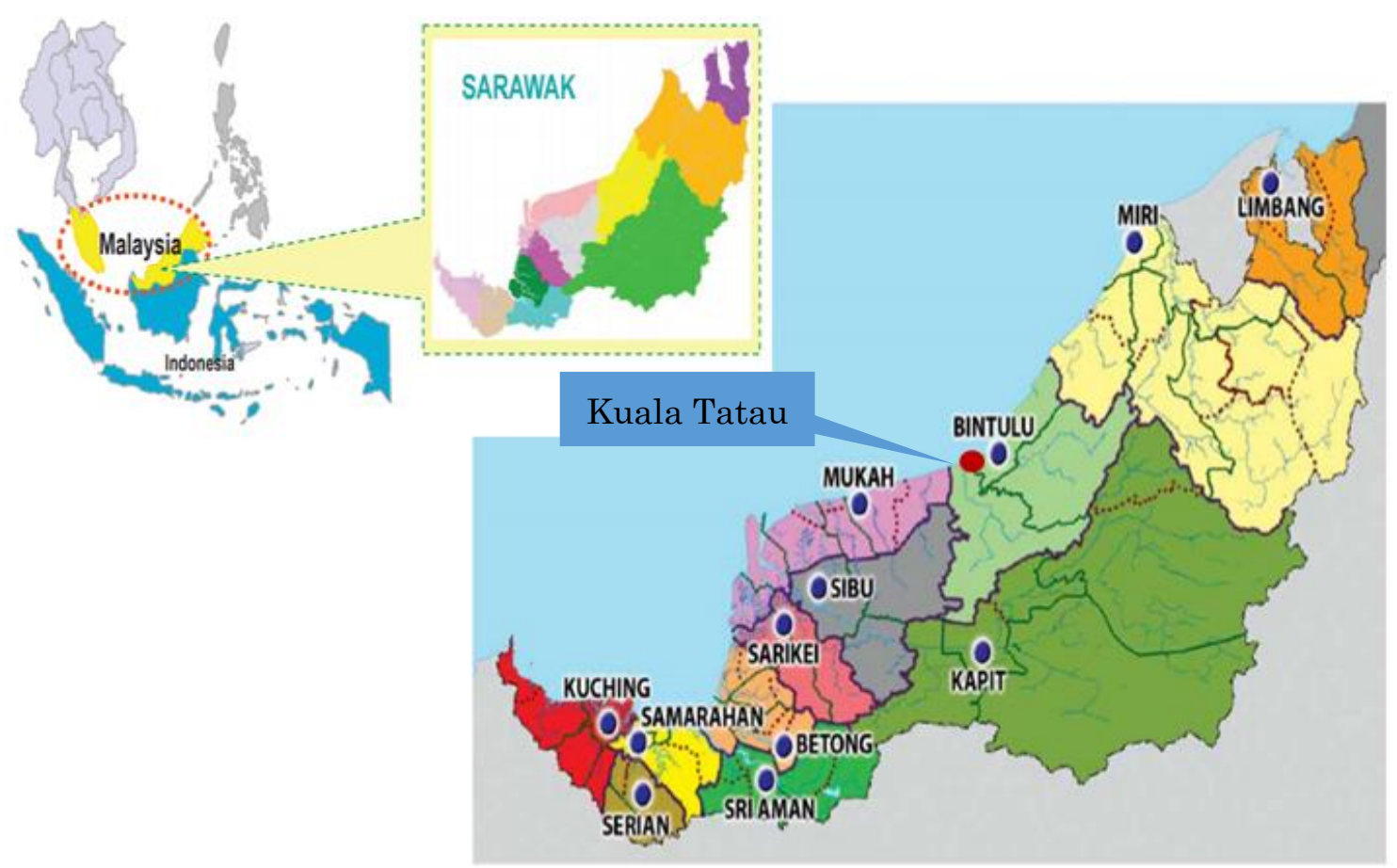

Figure 1: Kuala Tatau in Sarawak

(Source: http://www.mapsofworld.com/malaysia/states/sarawak-map.html)

Most of the farmers that involved in this study had utilized traditional and semi traditional agricultural method in paddy cultivation whereby they are using modern method such as using pesticides, fertilizers and others as shown in Figure 2 and Figure 3. They also believe in social taboos and local knowledge in paddy cultivation.

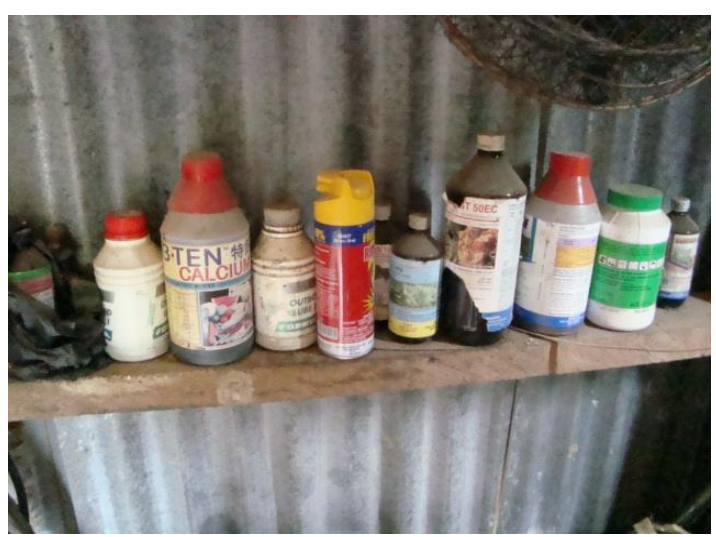

Figure 2: Pesticides and fertilizers used by the farmers in two villages (Souce: Fieldwork, 2013)

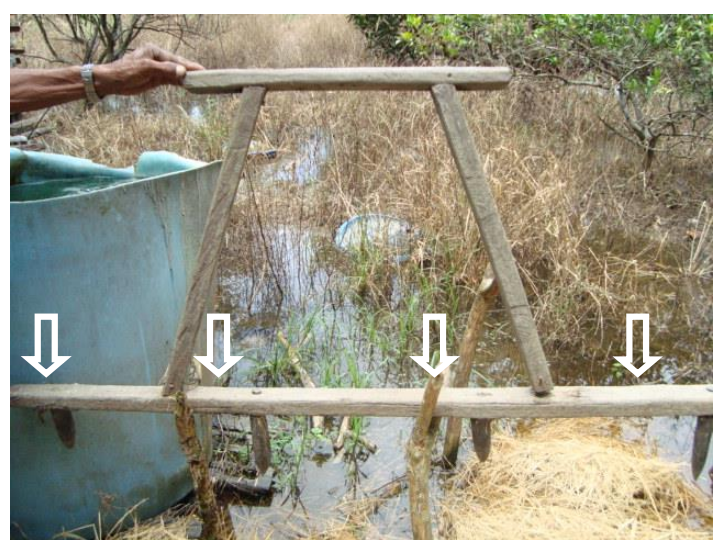

Figure 3: Seedling tools used during the planting process

(Source: Fieldwork, 2013)

The paddy yields were used for household consumption and some farmers sell the surplus to buy basic needs. Based on the observation and interview with the respondents, the acreage of land for paddy cultivation and the number of farmers has decreased as discussed in the next section in this paper. No official data found regarding on this issues. 


\section{ISSUES AND PROBLEMS FACED BY RURAL FARMERS IN PADDY CULTIVATION}

The study showed about five factors or issues that contribute to the problems that has been faced by the rural farmers in paddy cultivation at the study area, such as migration among youth and farmers to other sectors, a weakening of agricultural land, issues in the distribution of agricultural aids and subsidies system, competition in pest control with oil palm estate, as well as drainage and irrigation problem as discussed.

\section{a. Migration among youth and farmers to other sectors}

As the issue of poverty is commonly associated with agricultural sector like paddy cultivation activities, it is observed that this agricultural sector does not attract today's youths. Lawa and Okeowo (2014) stressed that migration had its positivity as well as negative effect. The negative side often being seen was that migration from rural into urban areas tends to deplete the agricultural labor force as it is the able-bodied young men who usually move out. With no commensurate substitution of capital in place of the displaced labor, agricultural productivity tends to fall in the source regions.

However, this negative effect can only be fully evident in cases where out-migration is on a permanent or long term basis. The industrial development in Bintulu has attracted the youths and old implementation of SCORE's ${ }^{1}$ (Figure 4) core industries such as in aluminum, silicon, oil and gas. farmers away from the paddy fields by offering higher wages and the promise of better lives especially after the women and those who have been working in the paddy cultivation activities have also joined the emigration drive; with some switching from tilling the paddy fields on a full time to a part time basis.

${ }^{1}$ SCORE is referred to as Sarawak Corridor of Renewable Energy now firmly established as one of Malaysia's five economic corridors. It is a part of the government regional development project that

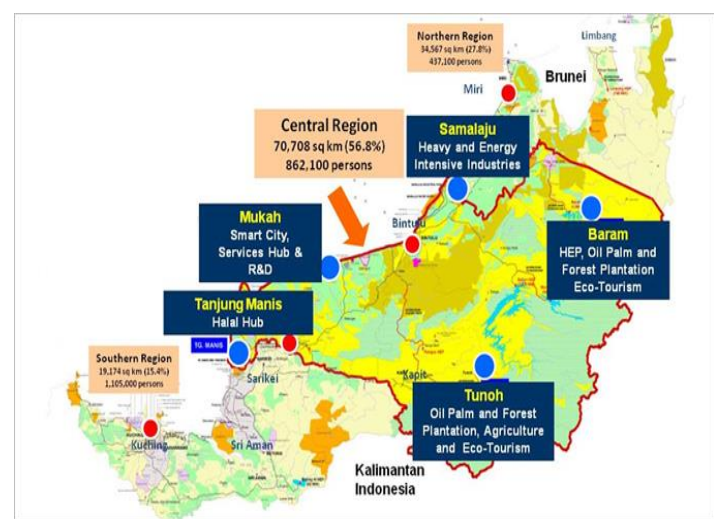

Figure 4: SCORE's Development Area (Source: RECODA, 2015)

In Sungai Semanok, families have also been split up with the men working in Bintulu, hence leaving their wives to work in the paddy fields by themselves. At the same time, there is also a husband and wife who worked in Bintulu by making the cultivation of rice as a part-time activity in which women farmers spend in the fields only during weekends, holidays and harvesting season. This phenomenon also occurs in Kuala Serupai where the community migrates to find job in Bintulu and working in private oil palm plantation. This situation clearly illustrates how rapid industrialization has affected not only the lives of those involved in paddy cultivation but also in their economic activity itself.

\section{b. A weakening of agricultural land}

Rapid urbanization process and industrial development in Bintulu also led to the reduction of agricultural land especially for paddy cultivation in Sungai Semanok. This problem is also contributed by the change of land use pattern from paddy sector to private oil palm plantations development owned by private sectors and collaboration between the state government and private sectors as shown by Figure 4. In addition, some villagers also sold their land to outsiders because their children did not take care of the land; no children to inherit

was launched in 2009. There are five growth poles selected for 10 high impacts development project such as oil-based industries, aluminium, oil palm, marine, livestock and others. 
the land and; sold due to urgent need for money over some emergency matter. Moreover, agricultural lands are also converted to infrastructure project such as coastal road especially at Sungai Semanok area and to some extend at Kuala Serupai. Based on observation, this phenomenon had also decreased the quantity of local food supply because the paddy farm is also used to plant a variety of other crops such as corn, eggplant, taro, gourds and some local vegetables for self sufficiency and sold for extra income especially used for emergency matter.

The decline in the number of paddy farmers and the reduction of the areas for paddy cultivation have also led to the abandonment of the local knowledge such as berdandang system ${ }^{2}$ as illustrated in Kuala Serupai as Freeman (1955) mentioned that reciprocal activity such as 'gotong royong' culture was not practiced due to the decreasing of agricultural land size. Now, the farmers have to hire laborers in addition to buy pesticides and fertilizers leading to higher input costs. Refer to Ghaffar and Osman (1995), this phenomenon, if left unattended, would eventually result in uncultivated and unproductive farmlands; a situation known as the de-agriculturalization of the rural economy.

It is also argued that local knowledge on paddy cultivation will eventually gone if the number of paddy farmers continue to decline as the knowledge passed down process from generations to another would no longer be practiced; as currently illustrated by the Ibans in Kuala Tatau. In addition, the practice of swidden system is a skill established and adopted to allow the environment to restore the cycle of agricultural use. It is also efficient and "effectively suited to the rather poor physical environment and specific ecological situations" (Spencer, 1966) and has proven to be sustainable over the millennia (Hong, 1987). Finally, the increase of labors and inputs costs directly caused the erosion of paddy sector in rural of Kuala Tatau. The decrease of the agricultural

${ }^{2}$ This system entails paddy farmers pooling their resources to prepare their lands for paddy cultivation land size also makes complicate the use of better production techniques but many of the techniques and equipment that can produce high production are difficult and expensive to utilize in a smallholding farms (Jomo, 1988). This phenomenon clearly shows that the diffusion process in rapid urbanization and development brings negative consequences to rural people (Jongudomkarn and Camfield, 2006).

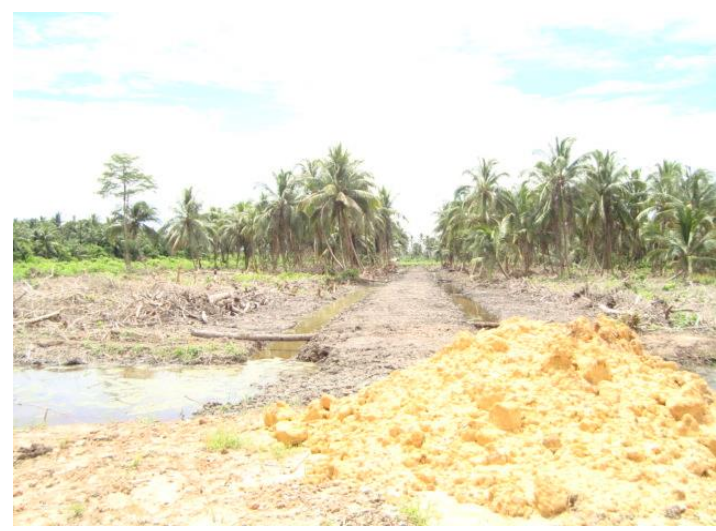

Figure 4: Land has been cleared for a small scale palm oil project (Source: Fieldwork, 2013)

\section{c. Issues of the distribution of agricultural aids and subsidies system}

The rice sector is facing the problems in the equity and quality of aids and agricultural subsidies distribution to both villages in this study. For example, the rice processing machines in both villages are not suitable to be use in processing local rice products whereby the thrashing or separation process of rice grain and straw was not complete due to the rice seed still attached with the straw. The milling process shows a maximum of broken kernels while the rice should have a minimum of broken kernels. There is also no explanation session by agriculture department on the use of fertilizers and pesticides and the procedure to use it. Refer to King (1992), an old issue in the Sarawak agricultural sector, whereby, the local farmers who received subsidies and agricultural aids have been selling it's to Chinese traders for a

through the sharing of manual efforts and the associated agricultural inputs; thus effectively reducing the costs borne by the paddy farmers. 
higher price. Similarly, there are farmers who used false evidence to obtain subsidies and agricultural supports while they actually do not deserve it. It also causes wastage because farmers do not know how to use them properly due to low educational level among the farmers. Pesticides and fertilizer subsidies were seen as a modern approach used to eliminate pests and improve the quality of rice.

\section{d. Competition in pest control with oil palm estate}

In Sungai Semanok, farmers are competing with large privately-owned oil palm estate in an effort to control pests. The ability of oil palm industry to buy a more expensive and high quality pesticide lead to more pests moving from the oil palm area to the paddy farms as a new habitat, which is less susceptible to the poison where farmers are practicing local knowledge by means of manipulating pests. This problem is also faced by the farmers as an internal factor that contributes to the decline in the quality and yield of rice. It is more critical as the numbers of farmers are decreasing because a small number of farmers need to compete with pest and it automatically weakens the pest control and increase labors costs.

\section{e. Drainage and irrigation problems}

The labor migration from rice sector to the industrial sector in Bintulu is also due to irrigation and drainage system problems that affect paddy cultivation, especially at Kuala Serupai. The drainage system is used to transport agricultural products such as rice, coconut and vegetables from the field. However, the failure of the government agencies to solve the problem of a shallow trench, water hyacinth, weed and grass overgrown cause the dry soil problem and lead to the decrease of crop yields. The situation had not been resolved for a long time, hindering efficient transportation of agricultural products to the market, for example in the case of coconut, the farmers are losing out because the problems obstruct efficient collection and transportation of coconut despite the high market value of coconut. In this case, the drainage and irrigation scheme are important because the farmer also using small boat to transport the agricultural yields from their farms. Despite many complaints was made to the Department of Drainage and Irrigation (DID) and the Department of Agriculture Sarawak (DAS), the problem take time to be solve due to bureaucracy process. At the end, the farmers are forced to change their job from the agricultural sector to the industrial sector in Bintulu and oil palm estate nearby.

\section{POLICY IMPLICATIONS}

The food crisis in 2008 clearly shows the importance of the consideration of the issues and problems that have plagued the country's rice sector through policy actions. It is important that the positive elements of the traditional way of life of the local people be maintained as much as possible to ensure paddy cultivation and the local knowledge on it to be preserved in the quest for industrialization and urbanization.

The social and economic ills associated with the process of industrialization and urbanization can be reduced if Ellis' (1998) suggestions on household strategies and rural livelihood diversification are adopted. Through the diversification of activities that can sustain and enhance their social capabilities, their cultural practices that are associated with paddy cultivation, such as the berdandang system, can be continued; thus enabling them to withstand market pressures. Actually, the failure of rural development programs rather than caused solely by external and internal factors of a country are in fact due to the neglect of basic local culture and knowledge systems in development (Chambers, 1997 and Kothari, 2005). Thus the inclusion of local paddy farming communities' policy inputs in major development programs as introduced by a new regional development project that was launched by the federal government in 2008 such as SCORE, is of utmost importance; more so because of the increase demand for rice in those areas.

The government agencies like the DID and DAS must be efficient and transparent in implementing their responsibilities by doing 
frequent monitoring of the programs that have been carried out, identify the problems occurring in the field and getting a farmer's feedback regarding the agricultural aids. Moreover, the ministry should take into account the voices from the grassroots as incompatibility issues of weaknesses in the distribution system of agricultural aid.

All complaints should be taken into account in the design of agricultural policy and the distribution of agricultural subsidies in the future so that the waste of public money can be reduced and the subsidy distribution goals can be achieved. Action policy which is only done at a critical time as the introduction of Agro-Food Policy in 2008 as a reaction to the food crisis when it should be prolonged in order to assure the agenda of national food security. Moreover, previous study by Byerlee (1974); Sabot (1979); Stiglitz (1969) and Todaro (1980) stressed that agriculture is the source of employment for majority of the rural population as means to reduce rural to urban migration and raising the income of the rural people.

\section{CONCLUSION}

The issues and problems occurring in the rice sector in Kuala Tatau clearly shows that the phenomenon discussed is not an option by the farmers themselves, but they had to contend with the power of capitalism brought by the actors of development. The agricultural sector is subjected to a process whereby agricultural outputs and supplies are provided at low prices to non-agricultural sectors. Moreover the agricultural sector also pays high rates of taxation used to finance the activities of nonagricultural sectors whilst simultaneously being forced to buy agricultural inputs such as pesticides, fertilizers, machineries and others at high prices (Siwar and Chamhuri, 2009). Hence these have negative impacts on the incomes of farmers; resulting in an increase in poverty amongst them, and subsequently some will migrate to urban areas to search for employment in non-agricultural sectors.

The emphasis on sectors that are profitable and increase urbanization process without taking into account the importance of the rural sector, especially rice production and will eventually lead to the country facing a severe food crisis, shortage of labor in the rice sector and the critical density of urban population in the future. This phenomenon is really not in line with the government development agenda in reducing the development gap between economic sectors and urban and rural sector that was emphasized in every five years Malaysia Plan.

Out-migration from rural to urban was a common problem faced by the African countries, whereby, the rapid urbanization had caused inequalities in the country (Tabutin and Schoumaker, 2004). Moreover, the mass emigration of people from agricultural sector to seek employment in the non-agricultural sectors will lead to densely populated urban areas, social problems and greater demands for better infrastructure and public utilities. This begs the question of whether industrialization and urbanization are indeed the appropriate panacea for problems of uneven development. Nowadays, the Sarawak government has a proper rural and agriculture development plans through Economic Transformation Programs and Regional Development Project through the implementation of SCORE. Through SCORE, government also prospers selected area to be developed as a food basket including rice sector in existing area. Rural people such as farmers also will be benefits from these projects through infrastructure and socioeconomic project including hinterland area. New urban growth in SCORE area will buy a rural product such as foods from the farmers.

\section{REFERENCES}

Berma, M. (1955). Towards the National Vision Policy: Review of the Economic Policy and New Development Policy among the Bumiputera Communities in Sarawak. Journal of Malaysian Studies, 21(1), 2004, 211-256.

Chambers, R. (1997). Whose Reality Counts? Putting the First Last. London: Intermediate Technology Publications. 
Chamhuri, S. \& Chamhuri, N. (2009). Strategi dan Prospek Mencergas Semula Sektor Pertanian Negara. Ekonomi Malaysia ke Arah Pembangunan Seimbang. Idris, N. A. H. \& Yussof, I., Ed. Pp. 282-315. Bangi: Penerbit UKM.

Ellis, F. (1998). 'Survey article: Household strategies and rural livelihood diversification'. The Journal of Development Studies. 35 (1), 1-38.

F. Derek. (1970). Report of the Iban, 140-142. London: The Athlone Press, University of London.

Freeman, J.D. 1955. Iban Agriculture: A Report of the Swidden system of Hill Rice by the Iban of Sarawak. London: H. M. Stationery Office.

Ghaffar A.G \& Osman K. (1995). Values and development in Malaysian planning - a macro and micro perspective. Proceedings of the Fifth Malaysia Singapore Forum, Singapore.

Hong, E. (1987). Natives of Sarawak: Survival in Borneo's Vanishing Forest. Malaysia: Institut Masyarakat.

Jackson, J. C. (1976). Sarawak. Kuala Lumpur: Dewan Bahasa dan Pustaka.

Jongudomkarn, D. \& Camfield, L. (2006) Exploring the quality of life of people in North Eastern and Southern Thailand. Social Indicators Research 78, 489-529.

Kendawang, J.J., Tanaka, S., Soda, R., Logie, S., Wasli, M.E. \& Sakurai, K. (2005). Difference of rice farming practices of the Iban in a national boundary area in Borneo and its socio-economic background. Tropics, 14: 295-307.

Kothari, U. (2005). Authority and expertise: the professionalization of international development and the ordering of dissent, Antipode, 37 (3).

Lawa A. S. \& Okeowo T. A. (2014). Effects of Rural Urban Migration on Labour Supply in Cocoa Production in Ondo East Local Government Area of Ondo State. Academic Journal of Interdisciplinary Studies, 3 (7).

Majid, Z. (1982). The West Mouth, Niah in the Prehistory of Southeast Asia. Sarawak Museum Journal 31 (52 n.s), Special Monograph No. 3.

Masron, T., Fujimaki, M., \& Ismail, N. (2013). Orang Asli in Peninsular Malaysia: Population, Spatial Distribution and Socio-Economic Condition. J. Ritsumeikan Soc. Sci. Hum. 6, 75-115.
Spencer, J. (1966). Swidden system in Southeastern Asia. California: University of California Press.

Stiglitz, J. (1969). Rural-urban migration, surplus of labour and the relationship between urban and rural wages. The Eastern Africa Economic Review 2: 1-28.

RECODA. (2015). SCORE Areas. Sarawak Corridor of Renewable Energy. http://www.recoda.com.my/invest-inscore/score-areas/ [12 January 2015].

Tabutin, D. \& Schoumaker, B. (2004). The Demography of Sub-Saharan Africa from the 1950s to the 2000s. A Survey of Changes and a Statistical Assessment. Population-E, 1 (59), 455-555.

Taib, M. (1989). Iban Cultural Heritage in the Context of Present Day Malaysia. Sarawak Museum Journal. 2.

Todaro, M.P. (1969): A model of labour Migration and Urban Unemployment in less developed Countries. American Economic Review March.

Ugih, D. (2014). Sustainable Development, Local Knowledge and Cultural Systems In Agriculture: Case Study Of Iban Farmers at Kuala Tatau, Bintulu, Sarawak. Thesis. Universiti Sains Malaysia.

Walton, J. R. (1990). The Economic Structure of Sarawak. Margins and Minorities: The Peripheral Areas and Peoples of Malaysia. King, V. T. \& Parnwell, M. J. G., Ed. 130-146. Hull: Hull University Press. 